\title{
A STUDY OF WAQF ASSET MANAGEMENT SYSTEM OF INDIA (WAMSI) SOFTWARE: GOVERNANCE, UTILITY AND SOCIO-ECONOMIC IMPACT
}

\author{
Mohd Wasim Ali ${ }^{1}$, Anam Rakshan*2 \\ ${ }^{1}$ Professor, Department of Law, Aligarh Muslim University, Aligarh Email: \\ drwasimali@gmail.com \\ ${ }^{2}$ Research Scholar, Department of Law, Aligarh Muslim University, Aligarh. Email: \\ khan.anam4@gmail.com \\ Corresponding author: khan.anam4@gmail.com
}

(Received: $19^{\text {th }}$ October 2021; Accepted: $4^{\text {th }}$ November 2021; Published: $31^{\text {st }}$ December 2021)

Keywords:

Governance; GIS and GPS; Remote Sensing; WAMSI; Waqf;

A B S T R A C T
This study presents an analysis of the
management of waqf properties through
Remote Sensing and GIS, and GPS
techniques. In India, there is a large number
of waqf properties; according to the Sachar
Committee report (2006) titled Social,
Economic, and Educational Status of the
Muslim Community of India, the total area
under waqf properties at about 600,000
acres at a book value of approximately Rs.
6000 crore. Some famous waqf properties
are the Dargah of Moinuddin Chishti at
Ajmer or the Shahi Masjid at Fatehpur
Sikri. The Central Waqf Council undertakes
the management of Waqf to check gross
mismanagement and encroachment of Waqf
properties. The Ministry of Minority
Affairs, Government of India, in 2009 ,
developed the Waqf Asset Management
System of India (WAMSI), an integrated
online workflow-based information system
for managing the Waqf properties under the
control of various State/U.T. Waqf Boards.


The advantage of this software system is transparency in sharing up-to-date information to the public at large and keeping a check on the revenue generated for the welfare of society in conformity with the noble object of Waqf. The methodology used in the paper is a qualitative research method where available works of literature were reviewed, conceptual and data-based evidence were analysed. The paper explores how WAMSI could be very useful to the countries where the Islamic concept of Waqf is prevalent and in practice, particularly in West Asian, South Asian, and South-Eastern Countries like Afghanistan, Bangladesh, Egypt, Indonesia, Iraq, Iran, Malaysia, Thailand, and UAE.

Publisher All rights reserved.

\section{INTRODUCTION}

"Never will you attain the good [reward] until you spend [in the way of Allah from that which you love, and whatever you spend- indeed, Allah is Knowing of it"(3:92). Waqf is one of the most rewarding acts a Muslim can do in his or her lifetime. A person can reap the benefits of this act of charity when he or she is alive and also long after his or her death. According to a famous Hadith, when Umar asked the Prophet (SAW) about the land he acquired in Khaybar. The Messenger of Allah (SAW) replied, "If you wish, you may make the property an endowment. In addition, you can give its produce as sadaqah. Thus, that it can no longer be bought, nor be sold, nor may it be possible to give it away or bequeath it." Thus, Umar gave the land as Waqf.

The institution of Waqf is a unique feature of Islamic law for the socio-economic development and various public services provided to the community. Nowadays, it has been reduced to mere charity, although in earlier times, Waqf has successfully provided sustainable income and reduced poverty in Muslim countries. Some of the famous Waqf properties worldwide are Al-Azhar University, one of the oldest universities in the world; Cairo University in Egypt, King Saud University endowment in Riyadh-KSA, Darul Uloom Deoband and Aligarh Muslim University in India is also established on many waqf grants.

In a socially and religiously diverse and developing nation like India, society has divided into various communities and groups pushed by the socio-economic compulsion to struggle for their very survival and existence. Muslims socio-economic condition and educational 
backwardness in India have become so severe and evident that it has become a grave concern.

In the earlier times, the Muslims were economically strong and had a respected social presence in society. They had anticipated the gloomy future of the Muslims and have made a significant contribution to the economic and educational upliftment of the Muslims. They have created many Waqfs for Muslim society. It is interesting to note that there are tentatively more than 1500 million rupees worth of waqf properties in India; if utilised correctly, the income generated can considerably help in the upliftment and progress of the oppressed Muslims. However, Waqf Institution in India is highly neglected, due to serious mismanagement in the administration of Waqf properties; the reasons are many, like legislative loopholes, administrative lapses, and dearth of political interest, will and a total indifferent approach of the Muslim community. Above all, lack of honesty has given rise to the painful phenomenon that the waqf properties have become so easy to encroach on, even graveyards are not spared. Moreover, waqf properties with tremendous commercial potential are not receiving the much-needed repairs and maintenance, thus turning such attractive buildings into dilapidated structures. There is a general conception that waqf properties are a cheap commodity available in the commercial market.

The present academic venture is an essential attempt to establish that digitisation of Waqf Properties which not only be of great help in maintenance, preservation and governance of Waqf Properties in India, may go a long way to enhance the income of Waqf Properties, this may implement for various Social welfare Schemes for the upliftment of Muslims especially in the field of Muslim education.

\section{WAQF PROPERTIES MANAGEMENT IN INDIA}

The literal meaning of 'Waqf' is 'detention'. It signifies binding up property in perpetuity so that no proprietary rights can be applied over the corpus but only over the usufruct.

According to Abu Hanifa, "waqf signifies the appropriation of a particular article (corpus) in such a manner as subjects it to the rules of divine property".

According to Kazi Abu Yusuf "Waqf is the detention of a thing in the implied ownership of Almighty God, in such a manner that its profit may be applied for the benefit of Human beings and the dedication when once made is absolute so that thing dedicated can neither be sold nor given nor inherited". In Jewun Doss v. Shah, Kubeer- Ooddin, the Privy Council held that after the creation of Waqf, "the right of the waqif is extinguished, and the ownership is transferred to the Almighty". Fatawa-i-Alamgiri declares that "decrees in this country are given according to Abu Yusuf". Subscribing to the opinion of Privy Council, Supreme Court of India in Syyed Ali v. A.P. Waqf Board, Hyderabad held that "a waqf is a permanent dedication of property for the purpose recognised by Muslim law as pious religious or charitable and property having been found as 
waqf would always retain its character as a waqf. In other words, once a waqf always continues to be so far all the time to come and further continues to be governed by Waqf Act, and a grant of patta in favour of Mokhasadar does not affect the original character of Waqf property". The person who makes Waqf is known as Waqif (dedicator of property), and Mutawalli or administrator is appointed by Waqif for managing a waqf property.

On 9 March 2005, the Prime Minister's Office (PMO) had issued the Notification for the constitution of the High-Level Committee for preparation of the report on the Social, Economic and Educational Status of the Muslim Community of India headed by J. Rajinder Sachar. The committee submitted the report in 2006 titled Social, Economic, and Educational Status of the Muslim Community of India. According to the report, India's total area under waqf properties is about 600,000 acres at a book value of Rs. 6000 crore. Since the market value is about half a century old, the current value will be several times more, and the market value has been estimated at 1.2 lacs crores as per the committee headed by Justice Shashvat in 2011 . The findings of this report further reveals that the annual income from these properties is only about 163 crores which amount to $2.7 \%$ of book value and found "a severe shortage of muslim government officers to manage waqf properties". If these properties are put to effectual and profitable use, they can produce at least a minimum return of $10 \%$, which is about Rs 12,000 crores per annum, and the income so generated can be used to improve the socio-economic and educational status of Indian Muslims.

During the Muslim Rule, the Mutawallis administered the waqf properties under the supervision of Qazis (judge of Shari'ah Court). The same Administrative structure initially continued by the British Rule in India, and later discontinued the policy in the 19 Century.

The Government of India passed the Waqf Act 1954, a Central Waqf Council in Delhi and Waqf Boards in most State Capitals controls the administration of waqf properties in the country under the Ministry of Minority Affairs.The Waqf Act 1954 was amended several times by successive Central and State laws and finally in 1995 was repealed and replaced by the Waqf Act 1995, which was later amended by the Waqf Amendment Act 2013.

\section{WAMSI SOFTWARE: AN OVERVIEW}

Waqf Asset Management System of India (WAMSI) is a project initiated by the Ministry of Minority Affairs, Government of India on the recommendation of the 9th Joint Parliamentary Committee in close consultation with the National Informatics Council (NIC), was launched in December 2009. After evaluation, it is further continued during 2017-18 to 2019-20 to $100 \%$ digitised the waqf records and computerised the core activities of all State/U.T. Waqf Boards in India. The Central Waqf Council (CWC) is the nodal agency for the implementation of the scheme. 
The advantage of this software system is transparency in sharing correct facts and figures to the public at large and keeping a check on the revenue generated for the society in conformity with the noble concept of Waqf. Satellite Imageries driven Geographic Information System (GIS) based on GPS Coordinates of the vertices of Immovable Waqf Properties is seamlessly integrated with WAMSI, which helps identify the encroachments (if any) over the period.

The income derived from Waqf Properties should be utilised to benefit the poor, marginalised, and underprivileged sections of society in the name of Allah, according to the basic principle of Waqf, like setting up institutions such as universities, colleges, schools, hospitals, and skill development centres and maintaining religious institutions (For example Madarsas, Mosques, Dargahs, graveyards).

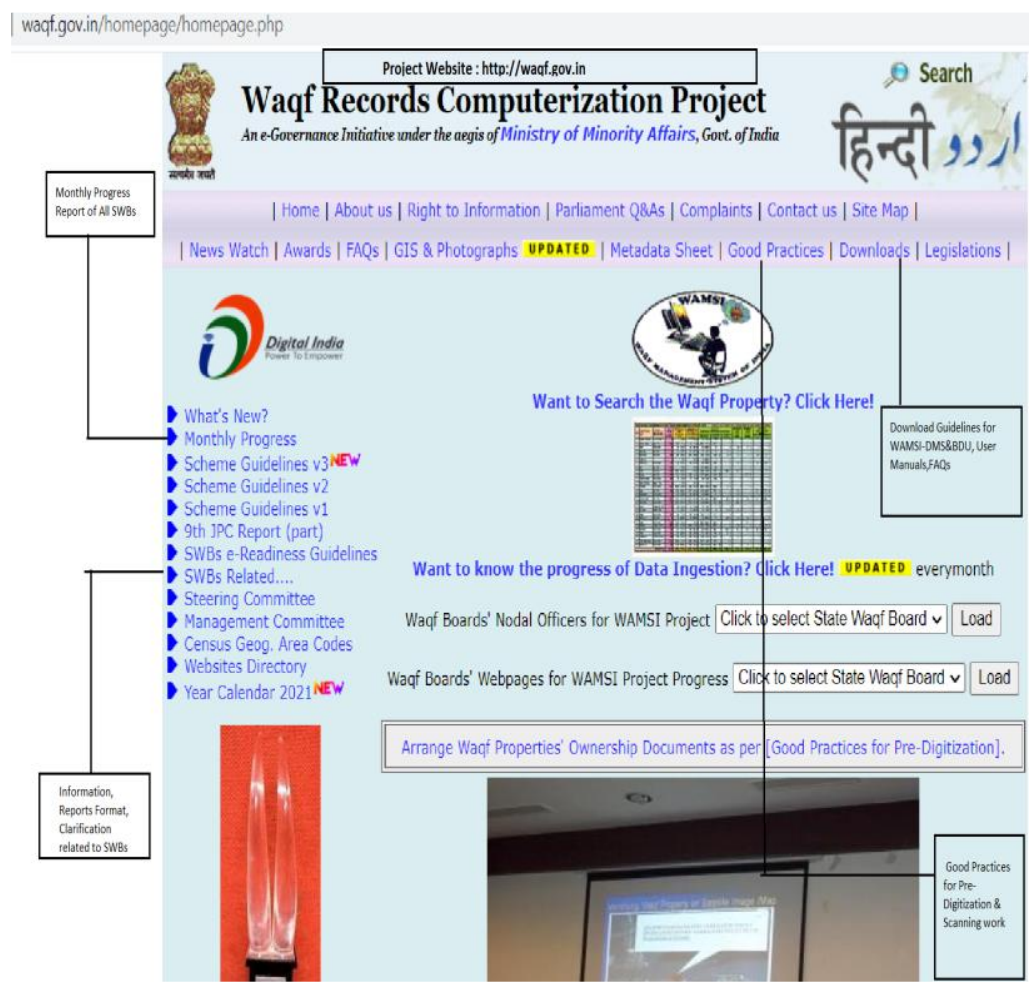

Figure 1: WAMSI Website homepage screenshot.

GOVERNANCE OF WAQF THROUGH WAMSI

Waqf properties are dispersed throughout the country, even a primary survey of waqf estates has not been conducted yet in most states. There is very little development of waqf assets, and a significant amount of revenue that could have been generated for community welfare projects has been squandered due to non-development and large-scale intrusion of waqf lands. 
As a result, in its Ninth Report, the Joint Parliamentary Committee on Waqf recommended computerization of the records of the State Waqf Boards and central financial assistance to these Boards in order to rationalise data keeping, introduce transparency in records, and computerise the various functions/processes of the Waqf Boards, as well as the development of a single web-based centralised application.

Table 1: Project WAMSI Online System in a Snapshot

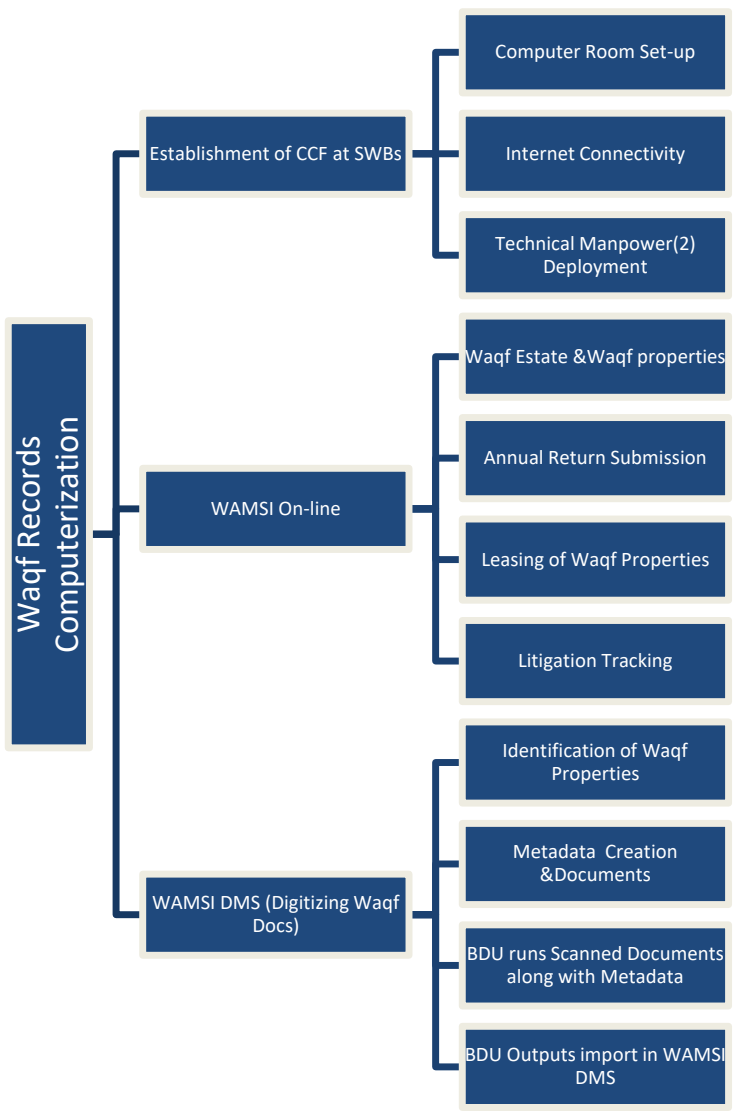

* Establishment of CCF at SWBs: The Ministry of Minority Affairs released funds to the State Waqf Boards (SWBs) for setting up the Central Computing Facility (CCF) to digitize the work according to the Ministry guidelines. It includes:

1. Setting up Computer Rooms

2. Providing High-speed Internet Connectivity

3. Technical Manpower Deployment 
* WAMSI On-line System: is an internet-based system comprising of the following -

1. Registration

2. Return

3. Leasing

4. Litigation

The scheme also involves-

- the annual return filing of each assessable Waqf Property and application of the workflows for leasing and tracking litigations,

- digitally preserving the documents of waqf properties ownership, and

- To facilitate easy recovery of documents required in litigations.

* WAMSI DMS System: Document Management System (DMS) is an offline system installed in the State Waqf Boards computer exclusively dedicated to the software. It is meant for storing scanned waqf properties documents.

- DMS-BDU Utility: WAMSI Bulk Data Updation (BDU) has been designed to capture Metadata Fields of Waqf properties \&upload scanned documents of the properties.

\section{WAQF PROPERTIES MANAGEMENT THROUGH COMPUTERISATION}

On the recommendation of the Joint Parliamentary Committee on Waqf, a Central Sector Scheme of "computerization of the Records of state/UT Waqf Boards" was launched by the Ministry of Minority Affairs ,Govt. of India on December 2009 i.e., during 11th Plan period. Under the scheme, the Ministry (MOMA) released funds to the state Waqf Boards for setting up the Central Computing Facility(CCF) to computerized the work of the scheme as per guideline framed by the Ministry. The scheme is continuing during the 12th Plan Period .The Ministry has now involved the central Waqf council as a nodal agency to complete the remaining work of Phase -I by engaging an outsource agency. The Ministry has released a total sum of Rs.8.80 crores to the council in three instalments. Computerization aims to achieve phase-wise objectives. In the First Phase, objectives are as under:-

- To ensure that Waqf data is surveyed correctly and cross-checked against various computer databases maintained at the state level, such as those maintained by Revenue Departments.

- To increase office productivity and produce timely reports on a variety of administrative issues.

- Creation of a centralised and web-enabled database for the stakeholders.

- Properties Registration Management of Waqf Boards.

- Muttawalli Returns Management system.

- Leasing of Properties Management system.

- Litigations Tracking Management system. 
- Documents Archiving \& Retrieval Management system.

- GIS of Waqf Properties

- Funds Management to Mosques, Durgah, Kabristan, Imams, Muazzins, Widows, Girls Marriages, Scholarships, Schools, Hospitals, Dispensaries, Musafirkhanas, Skill Development Centres.

- Loans Management for Development Of Urban Waqf properties

- Right to Information Act compliance

At the outset of the computerisation process, Immovable Waqf Properties were reported by 29 State Waqf Boards as 3,19,670. The Government of India started a "Scheme of Computerisation of the Records of State/U.T. Waqf Boards" in December 2009 to ensure the transparent management of all Waqf Properties and computerise the critical activities of all State Waqf Boards. During 2014-15 to 2020-21, CWC released Rs.55.86 crore to State Waqf Boards under the initiative. According to data on a dedicated web system called WAMSI (Waqf Assets Management System of India), 754428 immovable waqf assets have been recorded in the WAMSI Registration Module 1,88,476 waqf properties have been mapped using GIS. 3,31,872 records of waqf properties have been digitised for the first time.

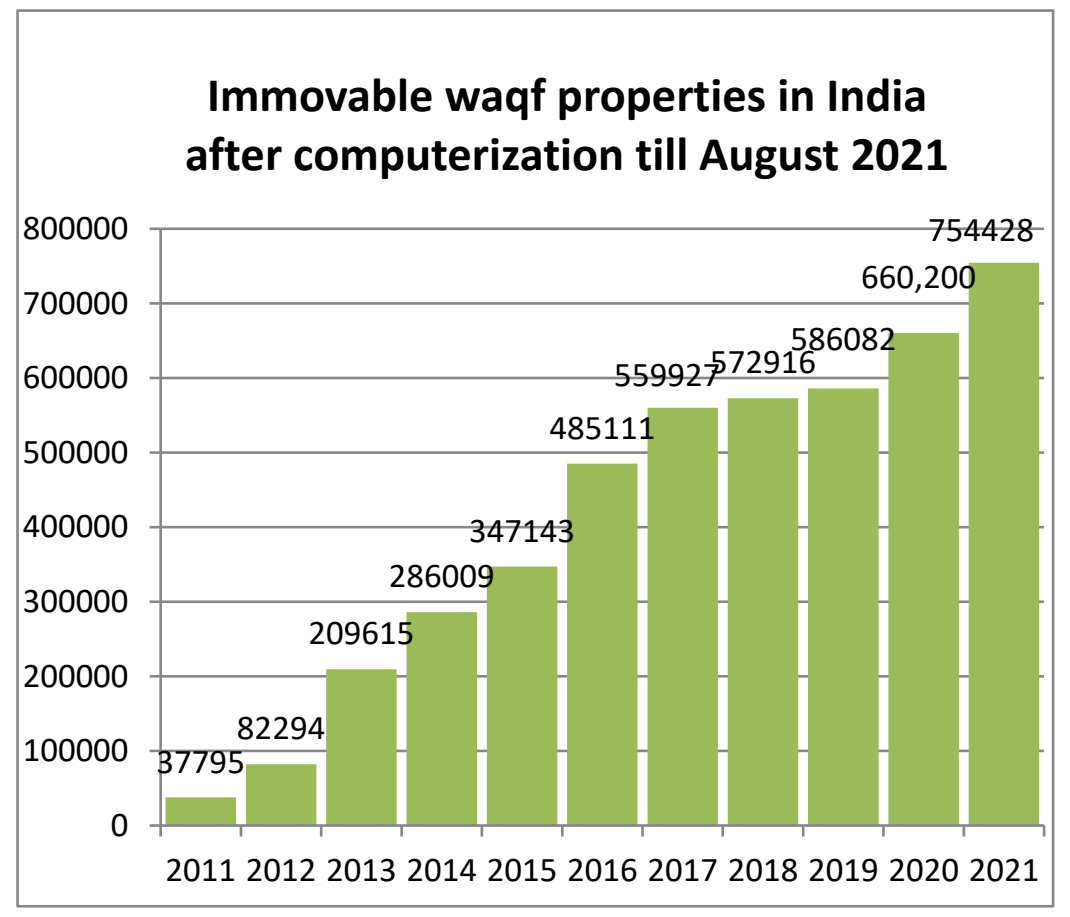

Figure 2: Immovable Waqf Properties in India after Computerization till August 2021 


\section{Encroachment detection of Waqf properties through GPS and Remote Sensing technologies}

In the 80th meeting of the Central Waqf Council, Minister of Minority Affairs India, Mr Mukhtar Abbas Naqvi, announced the geo-tagging and digitisation of all waqf properties to ensure transparency and safety of records. Ensure that all the waqf properties are utilised for educational empowerment and employment-oriented skill development for India's needy and economically backward Muslims.

Furthermore, encroachment on land resources is a prevalent issue brought about by vested interests or neighbours with nearby farmed grounds. For example, soil barriers are naturally altered, erased, or purposely broken down during agricultural sowing and monsoon season. Farmers continue to redraw these lines after each monsoon season Farmers. Thus they are likely to be altered. As a result, even a slight alteration now and then might turn into a massive change over time, resulting in the accumulation or loss of a larger area of farmed land-this unlawful accumulating (or as we can term it, encroachment). The management of land resources is complicated by encroachment. It is severe in Waqf Properties case as their ownership title lies with the Almighty, and therefore, nobody bothers to protect them.

Waqf properties are spread all over the country. In order to detect and prevent its encroachment, GIS/GPS of waqf properties has been done. Implementation of "Centralised web-based integrated workflow WAMSI on-line system (from now on called as WAMSI on-line system) has enhanced the efficiency of State/U.T. Waqf Boards by monitoring their waqf properties, prevent encroachment using GPS generated Layouts to get up to date information on revenue generated and trend analysis over a period of time to the status of leases, rent etc. to conduct legal cases on defaulters on time with the help of reports generated through GIS/GPS.

Through data analysis, it was discovered that Computerisation impacted the revenue of Waqf assets in India. All the stakeholders can monitor every aspect of Waqf Properties in India daily. They can also check for any mismanagement and report the wrongdoings to an appropriate \& competent authority for their redressals. It makes the whole process transparent.

Global Positioning System (GPS) Coordinates (i.e., a pair of Latitude $\&$ Longitude) locate a fixed point on the earth surface. If the fixed points (i.e., Vertices of any piece of land) are joined together in a cyclic order, then the resultant figure will be the layout of that piece of land on the earth surface.

If the same layout is superimposed on the Historical Satellite Imageries between different dates/years one-by-one, then the development in $\&$ around the layout can be noticed. Thus, encroachments could be 
detected easily. In WAMSI On-line System (WAMSI), GPS Coordinates of the Vertices of the Immovable Waqf Properties are entered as GPS Survey along with other attributes under the Registration Module. GPS Coordinates becomes part \& parcel of the WAMSI Database as permanent attributes for facilitating Geographic Information System (GIS) Reporting. At present, the Satellite Imageries Services of Google Maps \& Google Earth are used seamlessly through their APIs for drawing Properties layouts on Satellite Imageries. Neither WAMSI Database is shared with Google nor are Satellite Imageries purchased from Google.

Latitude, Longitude and Altitude are measured to define a complete and accurate GPS location for capturing the GIS image.

The Latitude and Longitude are decimal numbers with the following characteristics:

- Latitude between $0^{\circ}$ and $90^{\circ}$ : Northern hemisphere,

- Latitude between $0^{\circ}$ and $-90^{\circ}$ : Southern hemisphere,

- Longitude between $0^{\circ}$ and $180^{\circ}$ : East of the Greenwich meridian,

- Longitude between $0^{\circ}$ and $-180^{\circ}$ : West of the Greenwich meridian,

A Typical Reading of GPS Coordinates ( Important for WAMSI Online System)

A typical reading of GPS Coordinates of a Point on the Surface of the Earth looks like as $\left(41^{\circ}-26^{\prime}-57.40^{\prime \prime} \mathrm{N}, 23^{\circ}-15^{\prime}-57.51^{\prime \prime}\right.$ E) where $41^{\circ}-26^{\prime}$ 57.40" $\mathrm{N}$ is Latitude and $23^{\circ}-15^{\prime}-57.51^{\prime \prime} \mathrm{E}$ is Longitude. This kind of Pair/s is/are required to be entered in WAMSI On-line System as GPS Survey under Registration Module for either marking a Point Location or drawing a Lay-out of an Immovable Waqf Property on the Satellite Imagery for various GIS Reporting.

\section{THE UTILITY AND SOCIO-ECONOMIC IMPACT OF WAMSI IN INDIA AND OTHER COUNTRIES}

There are currently around 300,000 Mosques and 30,000 registered Madarsas in India, many of which are operating without basic amenities. With the increased revenue generated through Waqf properties thanks to digitisation, funds should be used to renovate and provide basic facilities such as water supply, electricity, more big prayer and educational rooms, and increased salaries for Imams and Muazzins. Madarsas in India, which were once the alma mater of many social reformers, great intellectuals, and freedom warriors, have now been relegated to complete poverty and neglect due to a lack of money, leaving them behind in the modern world.

WAMSI System could be utilised in handling the properties' affairs and other sectors where Immovable \& Movable Properties are treated as Public Assets.The NIC-PMU (WAMSI) Team might customise the WAMSI System to meet the needs of these applications at the minimum cost. The WAMSI system might be beneficial for better management and administration of Waqf assets worldwide, and with technological advancements, more functions could be added to it in the near future as per the needs and requirements. Counties like Turkey, Indonesia, Malaysia 
and UAE which are already technologically advanced and working with great interest in preserving their waqf assets, can come together for a universal platform to revive the waqf system in other developing Muslim nations to end poverty, protect the environment, funding in educational sector is a long-term investment for the development of the whole community.

\section{CONCLUSION}

We want to conclude the paper with the Hadith of Prophet Muhammad (SAW), "When a person dies, his deeds come to an end except for three: Sadaqah Jariyah (on going charity), a beneficial knowledge, or a righteous child who prays for him". The study is a modest attempt to explain the status of waqf property management and administration in India and the challenges faced by the Government in protecting the waqf properties from encroachers and land grabbers and fake litigations due to lack of waqf records. We discussed in detail the progress of computerization through WAMSI Online, which has proved to be quite successful in digitizing the waqf records and putting the waqf properties in the public domain, which helps in checking encroachment of waqf properties, it would be helpful in reducing Government expenditure, funding of small businesses, the real provision of waqf is to help the needy and poor by financing the small business through waqf funds is also an effective way to support the society.

The Government need to put the data collected through Remote Sensing technologies to better use by generating more revenue. The income generated should be utilized for educational empowerment through Schools, colleges, scholarships, accessible coaching facilities for higher education to young bright Muslim students. A national Portal should be generated to keep a record of income and expenses done by the State Waqf Boards in public Interest.

\section{ACKNOWLEDGEMENT}

We would like to express our gratitude to the Ministry of Minority Affairs, Government of India for the valuable information, data acquired through the Waqf Asset Management System of India (WAMSI) Project website and WAMSI online public interface for the digitisation of waqf properties and Encroachment detection and how to use GIS and GPS technology through Remote Sensing.

\section{REFERENCES}

Ali, Ameer, (1986). Mohammadan Law Kitab Bhavan.156.

Ambrose, A. H. A. A., Aslam, M., \& Hanafi, H. (2015). The possible role of waqf in ensuring a sustainable Malaysian federal government debt. procedia economics and finance, 31, 333-345.

Aziz, A., \& Ali, J. (2018). A comparative study of waqf institutions governance in India and Malaysia. Intellectual Discourse, 1229-1246. 
Cabinet Secretariat Government of India. (2006). Social, Economic and Educational Status of Muslim Community of India, Report, New Delhi 240. Available at www.minorityaffairs.gov.in

Gabil, H., Bensaid, B., Tayachi, T., \& Jamaldeen, F. (2020). The Need for Shari'ah-Compliant Awqāf Banks. Journal of Risk and Financial Management, 13(4), 76.

Government of India, "Sachar Committee Report," 240.

Hussain, S., Athar and Rashid, S., Khalid.(1973) Waqf Laws and Administration in India. Eastern Book Company.

Islam, M. Z. (2013). Legal enforceability of ADR agreement. International Journal of Business and Management Invention, 2(1), 40-43.

Jalil, M. A., Islam, M. Z., \& Islam, M. A. (2020). RISKS AND OPPORTUNITIES OF GLOBALIZATION: BANGLADESH PERSPECTIVE. Journal of Asian and African Social Science and Humanities, 6(4), 13-22.

Jewun Doss v. Shah, Kubeer- Ooddin (1840) 2MIA 390, followed in Vidhya Varuthi v. Balusami Ayyar, (1921) 48 IA 302.

Progress of computerisation, available at http://www.centralwaqfcouncil.gov.in/content/progress-computerisation

Rasool, T. (2017). Waqf Administration in India. Journal of Islamic Thought and Civilization, 7(1), 1-12.

Rasool, T. (2017). Waqf Administration in India. Journal of Islamic Thought and Civilization, 7(1), 1-12.

Reviving the Sunnah of Waqf, Available at www.waqf.org

Shariff, M. A., \& Ahsan, Z. F. (2021). Waqf development in India. Waqf Development and Innovation: Socio-Economic and Legal Perspectives, 157179.

Shia Central Board of Waqf Uttar Pradesh An on-line." work-flow based Waqf Properties Management". Available at www.upshiacwb.org/wamsi.aspx

Surah Al-Imran 3:92. 